Copyright (C) 2018 by Academic Publishing House Researcher

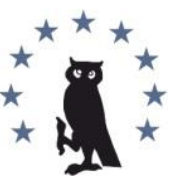

Published in the Russian Federation

European Researcher. Series A

Has been issued since 2010.

ISSN 2219-8229

E-ISSN 2224-0136

2018, 9(4): 314-328

DOI: $10.13187 /$ er.2018.4.314

www.erjournal.ru

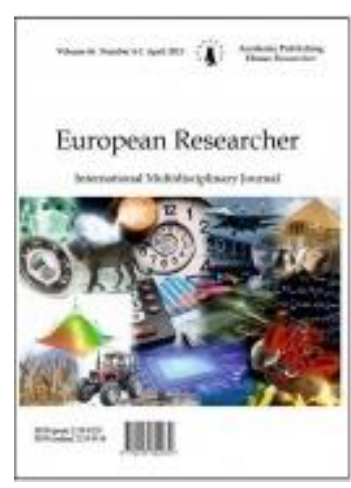

\title{
Analysis of Acceptance Level Related to E-Filing of Annual Tax Return of Personal Taxpayer (Case Study: Tax Office of Pratama Batang)
}

\author{
Suparna Wijaya ${ }^{\mathrm{a},{ }^{*}, \text { Dina Alifatul Ma'rifah }}{ }^{\mathrm{b}}$ \\ ${ }^{a}$ Indonesian State College of Accountancy, Indonesia \\ ${ }^{b}$ Directorate General of Taxes, Indonesia
}

\begin{abstract}
The Directorate General of Taxes (DGT) seeks to improve the satisfaction of taxpayers and all tax stakeholders in order to realize a high level of public trust in taxation services. In order to increase the level of compliance with the submission of the Annual Tax Return (ATR) of Personal Income Tax and the modern taxation system, DGT improves its services through e-filing. This study is aimed at analyzing the acceptance level of personal taxpayers for e-filing and finding out what factors affect the acceptance. The study was conducted by applying quantitative method. The hypothesis testing used Structural Equation Modeling (SEM) method and the processing used Lisrel 8.7 program. The research findings showed that the variables of compatibility and perceived ease of use have significant effect on perceived usefulness. Meanwhile, the variables of complexity, trust, and social influence do not have significant effect on perceived usefulness of taxpayers. On the other hand, the variable of social influences does not have significant effect on perceived usefulness of taxpayers. The variables of complexity and compatibility have significant effect on perceived ease of use. Meanwhile, the variable of perceived usefulness has significant effect on attitude towards using. However, it turns out that the variable of perceived ease of use does not have significant effect on attitude towards using. Conversely, the variables of attitude towards using, social influence, and facilitating condition have significant effect on behavior intention. Meanwhile, the variable of social influence which includes the role of the media, government, and tax officers in providing recommendations for the use of e-filing actually has effect on the taxpayer's behavior intention. In addition, the variable of facilitating condition which includes hardware and software availability, ease of access to e-filing site, and assistance of tax officers also have significant effect on taxpayer's behavior intention. Furthermore, the variable of trust does not have effect on taxpayer's perceived usefulness and behavior intention. Finally, the variable of perceived risk does not have effect on taxpayer's behavior intention.
\end{abstract}

Keywords: perceived usefulness, perceived ease of use, attitude towards using, behavior intention.

\section{Introduction}

One of the strategic objectives of the Directorate General of Taxes (DGT) is to increase the satisfaction of taxpayers and all tax stakeholders in order to realize a high level of public trust in tax services. This is in accordance with the mandate of Law number 25 of 2009 concerning Public

\footnotetext{
${ }^{*}$ Corresponding author

E-mail addresses: sprnwijaya@gmail.com (S. Wijaya)
} 
Services and the direction of the President of the Republic of Indonesia regarding efforts to stop all forms of crime and irregularities and in order to improve DGT performance achievements. One effort to achieve a high level of satisfaction with taxation services is to improve the quality of service to taxpayers. To improve the quality of service to taxpayers so as to create excellent service, a Circular Letter of the Director General of Taxes number SE-84/PJ/2011 was issued concerning Excellent Service.

According to Leisink, P., Steijn, B. (2009) service is an activity or sequence of activities that occur in direct interaction between someone with another person or machine physically, and provides customer satisfaction. According to Perry and Hondeghem (2008) excellent service is the best service in meeting customer expectations and needs. Excellent service is based on service that refers to customer satisfaction.

Satisfaction is the level of one's feelings after comparing the performance (results) they feel with their expectations (Armstrong et al., 2014). Improving taxation services can be seen from the development of modern tax administration and information technology in various aspects of activities by submitting an Electronic Annual Tax Return (e-filing). Based on the Directorate General of Taxes Regulation number PER-1/PJ/2014, e-filing is a way of delivering ATR that is carried out online and in real time through the pages provided by DGT.

Based on the DGT performance report in 2017, it was stated that the growth of ATR delivery through e-filing as a whole amounted to $85.72 \%$ which became one of DGT's indicators in order to improve the excellent service for taxpayers. The level of formal compliance alone has only reached the level of $62.96 \%$. From Graph 1, the number of taxpayers who reported the Annual Tax Return (ATR) during the last three tax years 2015, 2016 and 2017, always increased. Until the end of May 2018, there were 8,289,184 individual taxpayers who had reported ATR through e-filing.

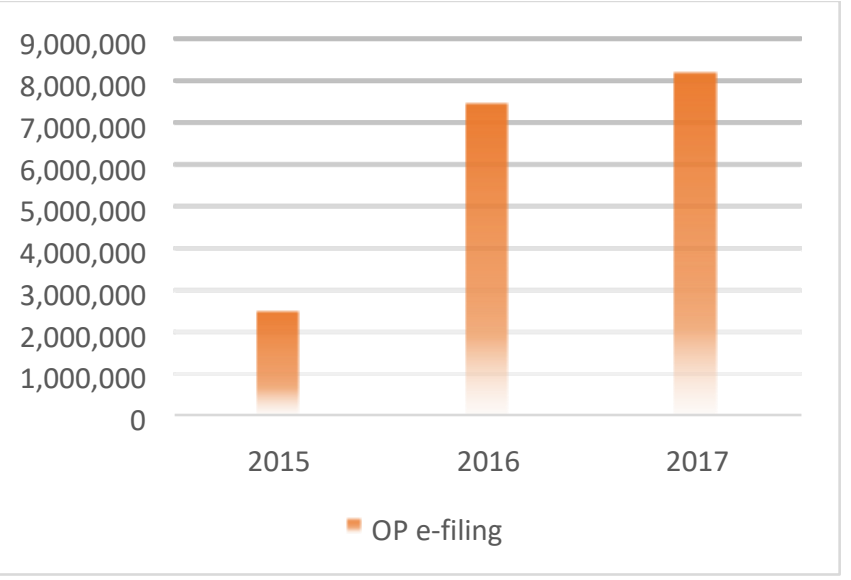

Fig. 1. Users of Personal E-Filing for the Last Three Years

Source: Directorate of Communication and Information Technology Transformation CITT of DGT

Tax Office of Pratama Batang is the First Tax Office located in Batang Regency whose working area covers Batang and Kendal Regencies. In 2017, the Tax Office of Pratama Batang became the only Tax Office that reached the number of revenue targets in the Central Java Regional Office I. However, the level of achievement of the e-filing target in the Tax Office of Pratama Batang was ranked twelve of the sixteen Tax Offices in the Central Java Regional Office I. Tax Office of Pratama Batang can only meet the achievement target of e-filing by $70.88 \%$. The number of taxpayers in the Tax Office of Pratama Batang based on the sources of the Data and Information Processing section in 2018 respectively are the 8937 agencies, 2452 collection agencies, 122,235 personal taxpayers, and others. This shows that the Personal Taxpayers has the largest composition; as many as $91 \%$. 


\section{Research Method}

\subsection{Research Approach}

This study was conducted by using quantitative approach in the form of survey. There was a two-phase project that was involved by researchers. In the first phase the researchers collected quantitative data and then analyzed the results. Next, the researchers continued the analysis of qualitative data from the results of answers to open questions. Overall, the objective of this design is to help qualitative data explain in detail the previous results of quantitative data.

\subsection{Data Collection Method}

The data collection method using primary data were obtained through distributing questionnaires to taxpayers in which the questionnaire will be filled in by the respondent (selfadministered questionnaire) manually or online. The researcher used structured questions with a Likert scale with arrange of 1 to 5 . In addition, the secondary data were obtained from sources originating from previous studies, supporting books, articles from magazines, internet sites, and other types of literature related to this study.

2.3 The Scope of the Research

This study aims to see what factors affect the taxpayers to use e-filing in their tax report. In its implementation, this study uses a minimum of 379 samples. The number of samples obtained from the Krejcie and Morgan's (1970) table in Sekaran (1992) in which the population is (N) 30,000 .

This study took the scope of the Personal Taxpayers of Tax Office of Pratama Batang. The distribution of questionnaires was carried out both directly and online using purposive sampling and was not limited to the number of samples in each area (non-quota sampling).

2.4 Research Variables

The variables in this research can be seen in Figure 2.

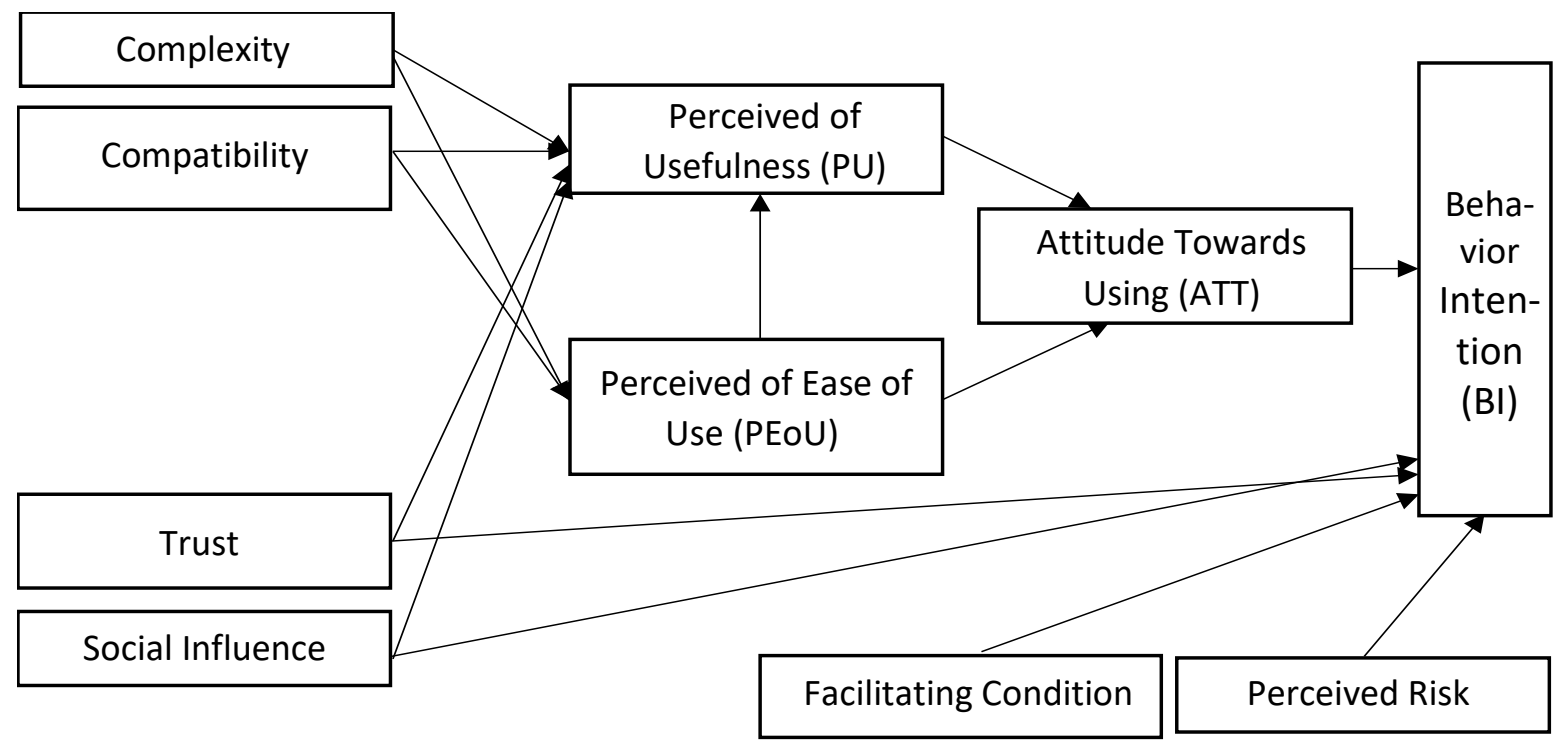

Fig. 2. Research Variables

2.5 Research Hypothesis

Based on the theoretical framework and findings of previous studies, the following hypotheses are proposed:

$H_{1}=\quad$ perceived risk in the use of e-filing has negative effect on the behavior intention in using the application in the following year 
$H_{2}=$ facilitating condition in the use of e-filing has positive effect on the behavior intention in using the application in the following year

$H_{3}=$ attitude toward using the use of e-filing has positive effect on the behavior intention in using the application in the following year

$H_{4}=$ perceived of usefulness the use of e-filing has positive effect on attitude toward using

$H_{5}=\quad$ perceived of ease of use e-filing has positive effect on attitude toward using

$H_{6}=$ perceived of ease of use e-filing has positive effect on perceived of usefulness

$H_{7}=$ complexity of the use of e-filing has negative effect on perceived of usefulness

$H_{8}=$ complexity of the use of e-filing has negative effect on perceived ease of use

$H_{9}=$ compatibility has positive effect on perceived of usefulness

$H_{10}=$ compatibility has positive effect on perceived of ease of use

$H_{11}=\quad$ trust has positive effect on perceived of usefulness

$H_{12}=$ trust has positive effect on behavior intention in using the application in the following year

$H_{13}=$ social influence has positive effect on perceived of usefulness

$H_{14}=$ social influence has positive effect on behavior intention in using the application in the following year

The method used to test the hypothesis is Structural Equation Modeling (SEM). SEM is used to examine and justify a model (Hair et al., 2012). Model visualization is carried out to reduce the level of error in the construction of a model in SEM. The program that will be used for statistical testing is the application of Lisrel 8.7 and SPSS.

\section{Findings and Discussion}

3.1 General Description of Respondent Characteristics

The respondents of this study were personal taxpayers who used e-filing in their ATR reporting. The distribution of questionnaires was carried out online and directly. The number of respondents who returned the questionnaire was 381 people and all the results of the response were used in this study. This number has exceeded the minimum number of samples required by Krejcie and Morgan (1970) in Sekaran (1992) for a total population of 30,000, i.e. 379 respondents.

3.2 Validity and Reliability Tests

The observed variable is considered to have good validity for its construct or latent variables if the $t$-value of the loading factor is greater than the critical value (1.645) and the standard loading factor is greater or equal to 0.50 (Wijanto, 2008). Wijanto (2008) added, if the standard value of the loading factor is $<0.50$ but still $\geq 0.30$ then the related variable can be considered not to be deleted.

A measurement model is considered to have good reliability to measure each of its latent variables if its construct reliability value (CR) is 0.70 or more and its variance extracted value (VE) is greater than 0.50 (Hair et al., 2012). However, variance extracted less than 0.50 is acceptable, because Fornell and Larcker mentioned that when VE is less than 0.50, but CR is higher than 0.6, then convergent construct validity is still reliable (Fornell, Larcker, 1981). 


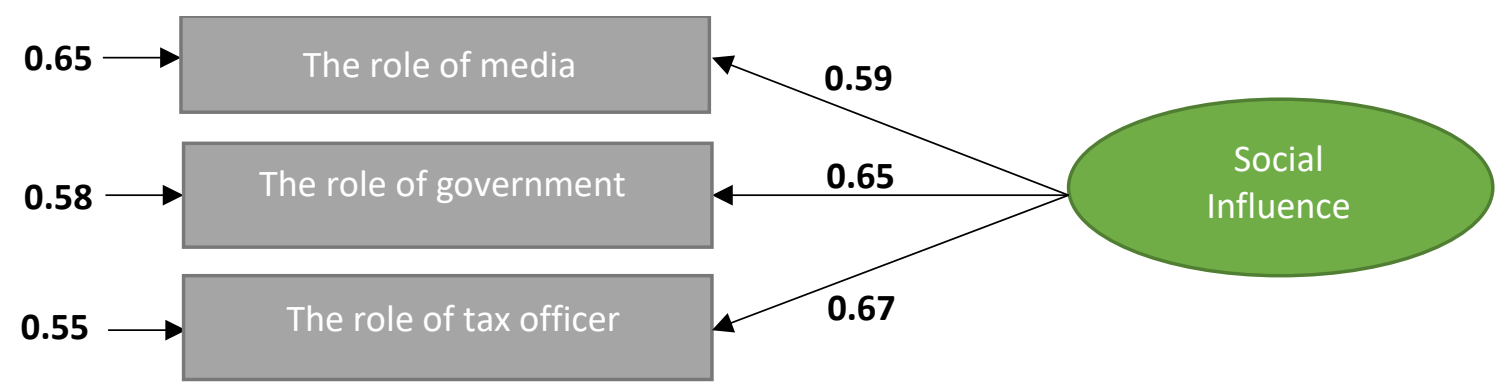

Fig. 3. Value of Loading Factor of Indicator Standard on the Latent Variable of Social Influence Source: Processed from Lisrel 8.7

The latent variable of social influence describes the perception of taxpayers on social influence in the use of e-filing. The findings showed that the observed variable role of the tax officer has the biggest contribution. Variance extracted obtained from the three observed variables to measure the latent social influence variable is 0.41 . This value indicates that 41 percent of the information contained in the observed variables can be represented by the latent variable of social influence.

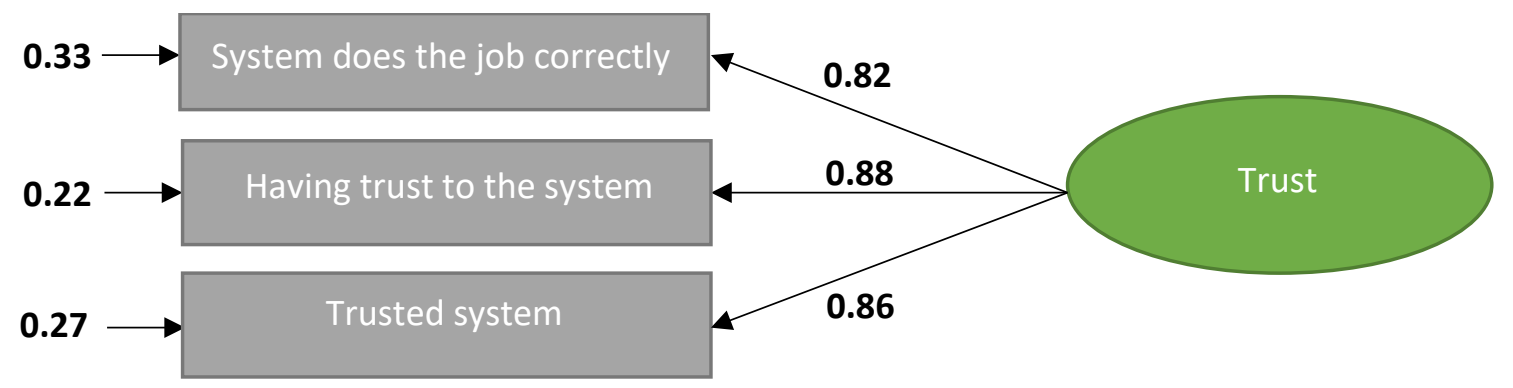

Fig. 4. Value of Loading Factor of Indicator Standard on the Latent Variable of Trust Source: Processed from Lisrel 8.7

The latent variable of trust describes the perception of taxpayers on trust in the use of e-filing. The findings showed that the observed variables of trust in the system has the largest contribution. Variance extracted obtained from the three observed variables to measure the latent variable of trust is 0.73 . This value indicates that 73 percent of the information contained in the observed variable can be represented by the latent variable of trust.

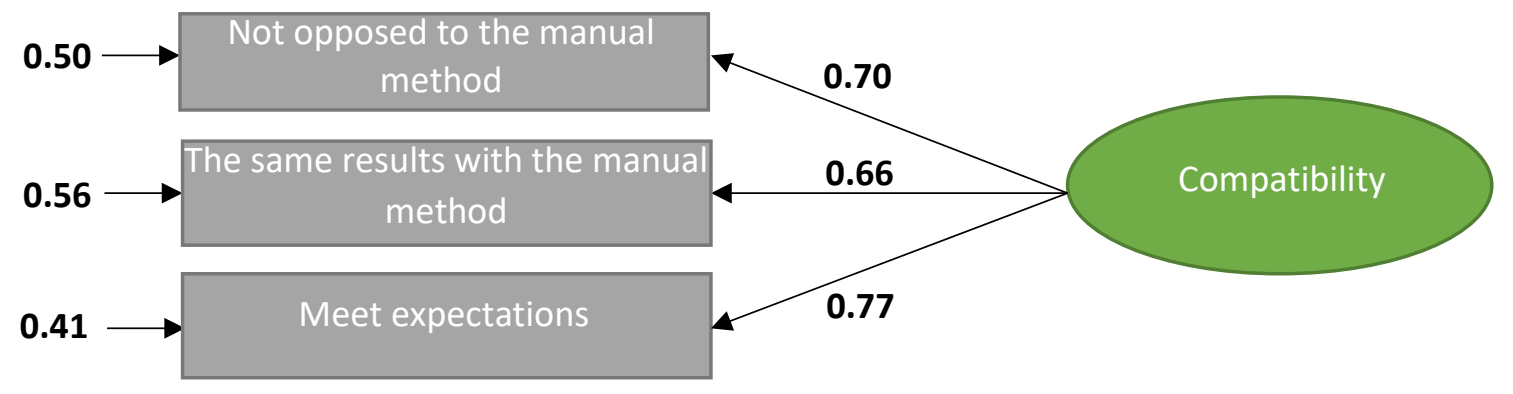

Fig. 5. Value of Loading Factor of Indicator Standard on the Latent Variable of Compatibility Source: Processed from Lisrel 8.7

The latent variable of compatibility describes the perception of taxpayers on the convenience of using e-filing. The results showed that the variables fulfilled the expectations of taxpayers on the application had the largest contribution. Variance extracted obtained from the three observed variables to measure the compatibility latent variable is 0.51 . This value indicates that 51 percent of 
the information contained in the observed variable can be represented by the latent variable of compatibility.

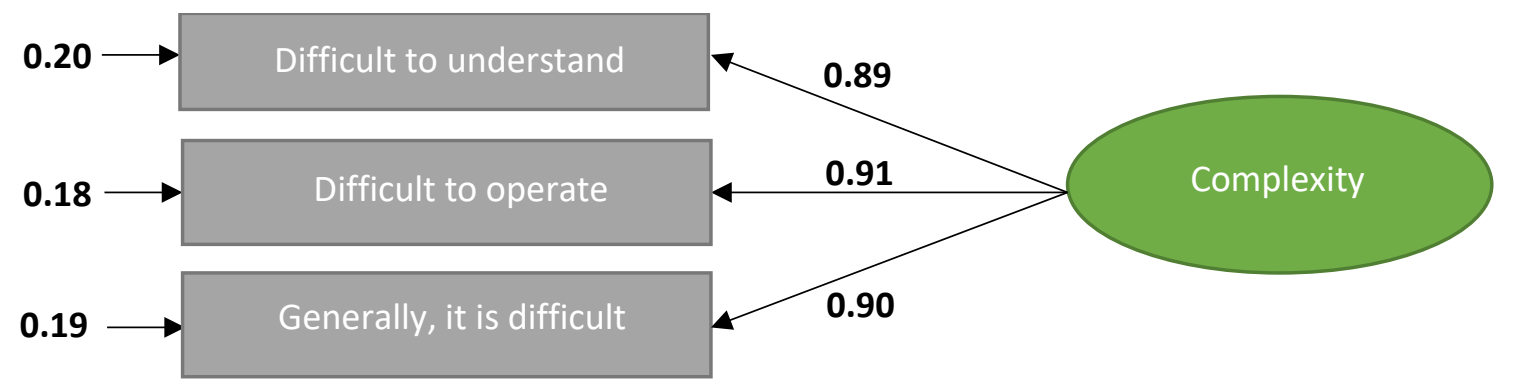

Fig. 6. Value of Loading Factor of Indicator Standard on the Latent of Variable Complexity Source: Processed from Lisrel 8.7

The latent variable of complexity describes the taxpayer's perception on the complexity of using e-filing. The research findings showed that the variable of 'difficult to operate' has the largest contribution. Variance extracted obtained from the three observed variables to measure the latent variable of complexity is 0.81 . This value indicates that 81 percent of the information contained in the observed variable can be represented by the latent variable of complexity.

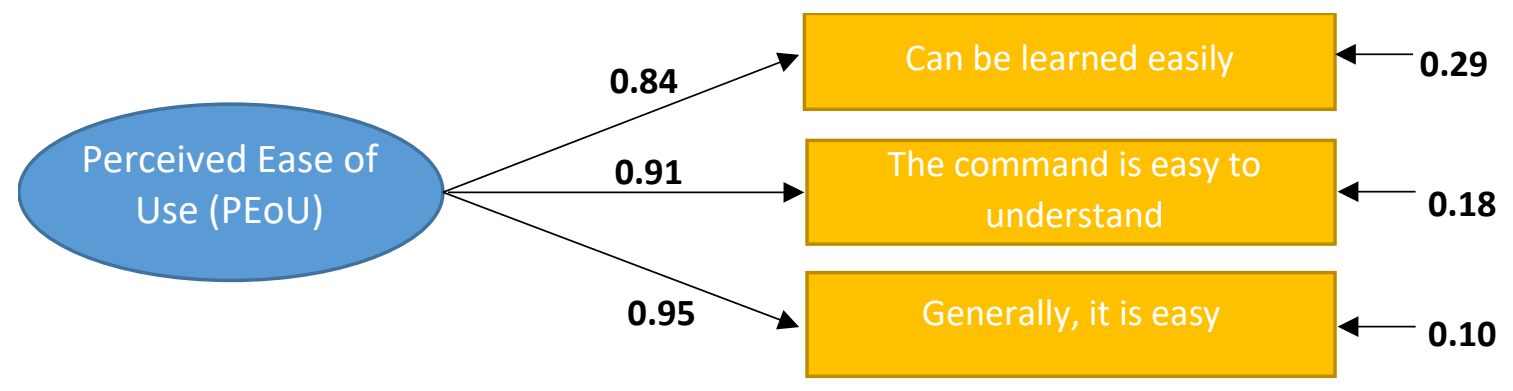

Fig. 7. Value of Loading Factor of Indicator Standard on the Latent Variable of Perceived Ease of Use Source: Processed from Lisrel 8.7

The latent variable of perceived ease of use describes the taxpayer's perception of the ease of using e-filing. The research findings showed that variable of 'generally, it is easy' has the greatest contribution. Variance extracted obtained from the three observed variables to measure the latent variable of perceived ease of use is 0.81 . This value indicates that 81 percent of the information contained in the observed variable can be represented by the latent variable of perceived ease of use.

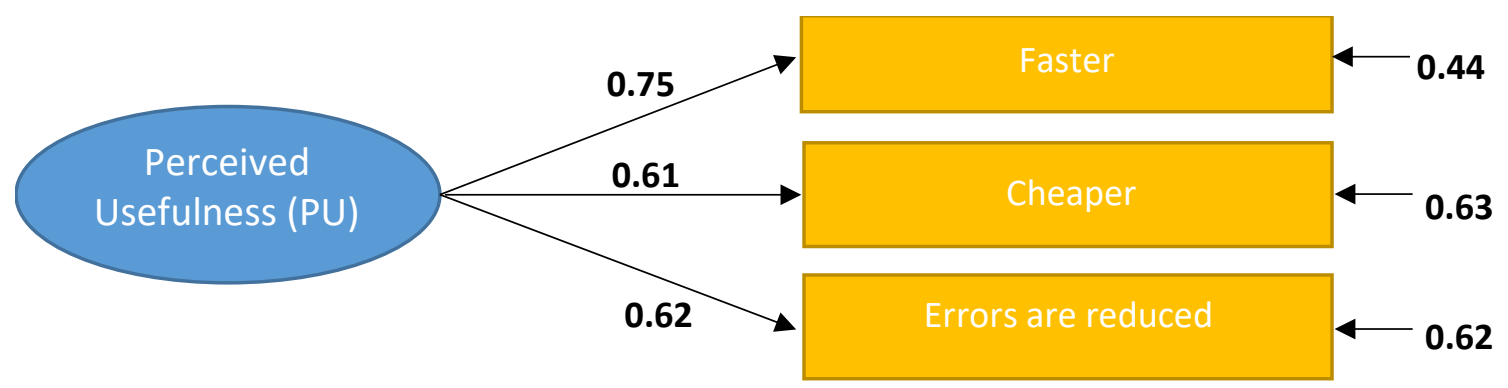

Fig. 8. Value Loading Factor of Indicator Standard on the Latent Variable of Perceived Usefulness Source: Processed from Lisrel 8.7

The latent variable of perceived usefulness describes the taxpayer's perception of the perceived benefits in the use of e-filing. The research findings showed that the observed variable of 
'faster' has the greatest contribution. Variance extracted obtained from the three observed variables to measure the latent variable of perceived usefulness is 0.44 . This value indicates that 44 percent of the information contained in the observed variables can be represented by latent variable of perceived usefulness.

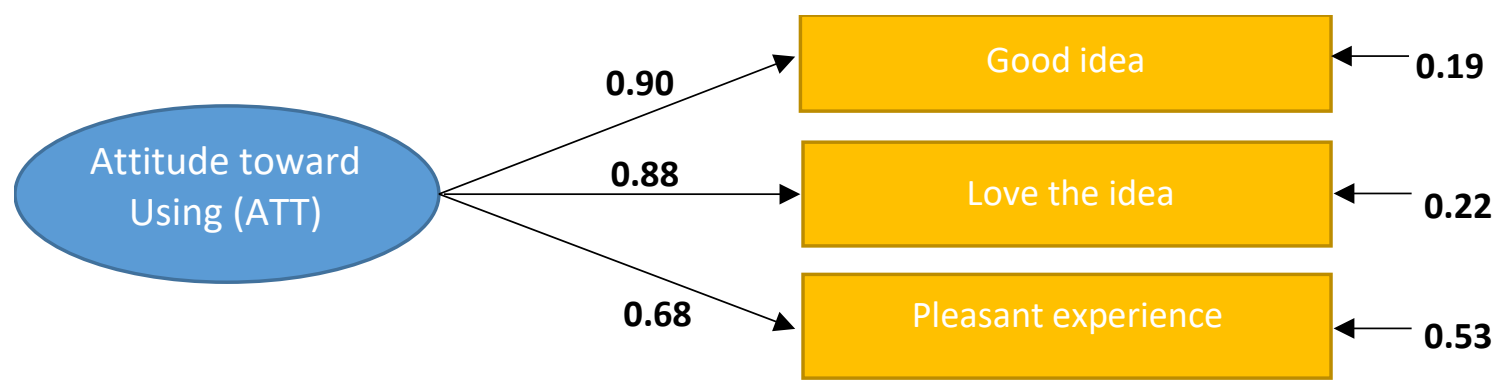

Fig. 9. Value of Loading Factor of Indicator Standard on the Latent Variable of Attitude Toward Using Source: Processed from Lisrel 8.7

The latent variable of attitude towards using describes taxpayers' attitude on the use of e-filing. The research findings showed that the observed variable of 'good idea' has the largest contribution. Variance extracted obtained from the three observed variables to measure the latent variable of attitude towards using is 0.69 . This value indicates that 69 percent of the information contained in the observed variable can be represented by the latent variable of attitude towards using.

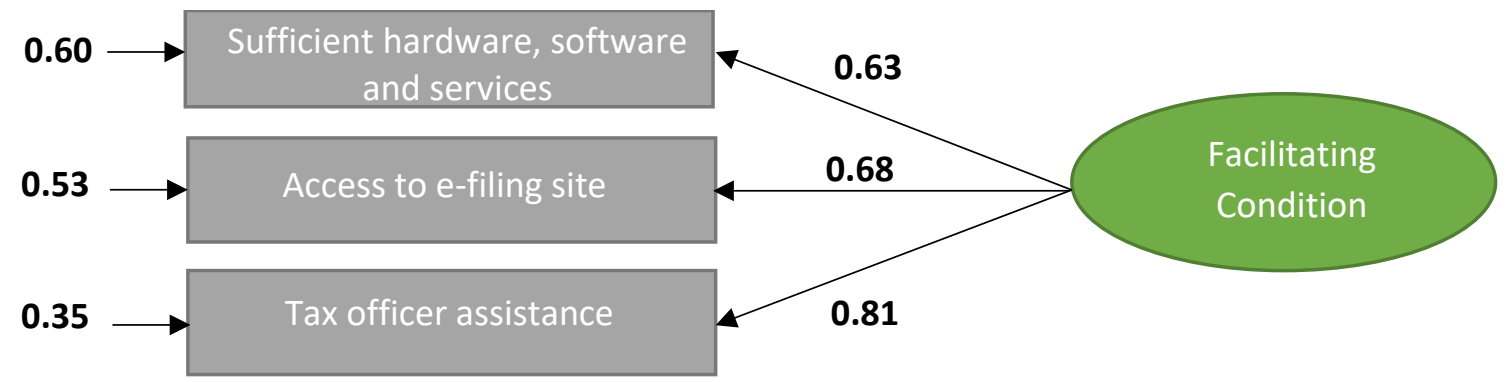

Fig. 10. Value of Loading Factor of Indicator Standard on the Latent Variable of Facilitating Condition

Source: Processed from Lisrel 8.7

The latent variable of facilitating condition describes the taxpayer's perception of the facilitating condition in the use of e-filing. The research findings showed that the observed variable of tax officer assistance has the largest contribution. Variance extracted obtained from the three observed variables to measure the latent variable of facilitating condition is 0.51 . This value indicates that 51 percent of the information contained in the observed variable can be represented by the latent variable of facilitating condition.

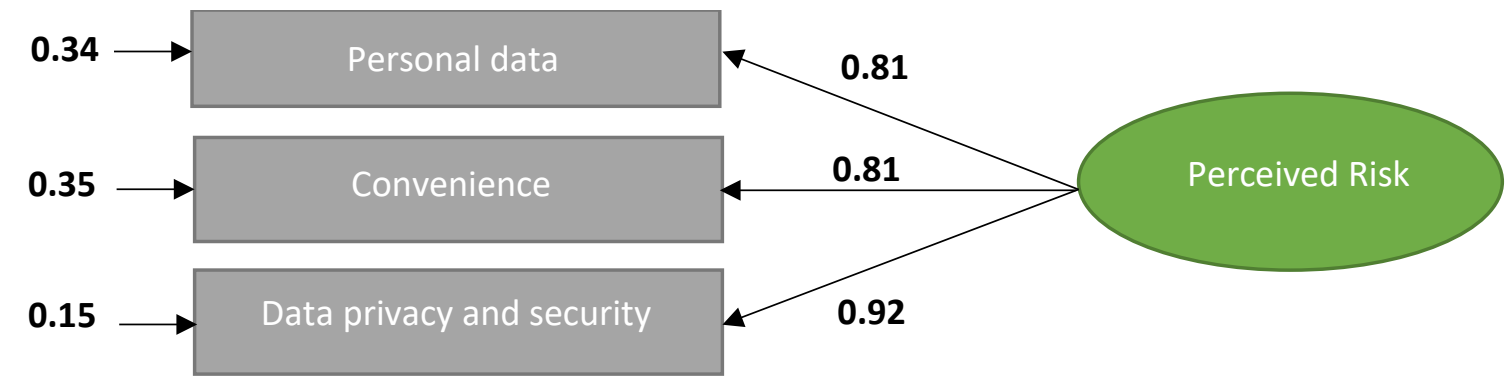

Fig. 11. Value of Loading Factor of Indicator Standard on the Latent Variable of Perceive Risk Source: Processed from Lisrel 8.7 
The latent variable of perceived risk describes the taxpayer's perception of the risks faced by the taxpayers in the use of e-filing. The research findings showed that the observed variable of 'data privacy and security' has the largest contribution. Variance extracted obtained from the three observed variables to measure the latent variable of perceived risk is 0.72 . This value indicates that 72 percent of the information contained in the observed variables can be represented by the latent variable of perceived risk.

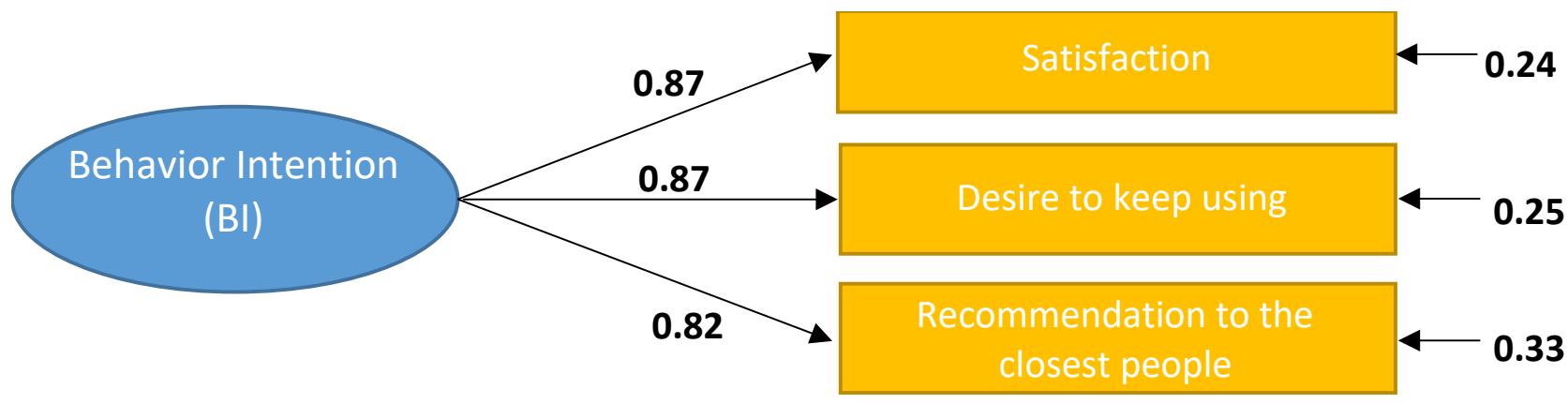

Fig. 12. Value of Loading Factor of Indicator Standard on the Latent Variable of Behavior Intention (BI)

Source: Processed from Lisrel 8.7

The latent variable of behavior intention describes taxpayers' behavior on the use of e-filing. The research findings showed that observed variables of 'satisfaction' and 'desire to keep using' have greater contribution. Variance extracted obtained from the three observed variables to measure the latent variable of behavior intention is 0.73 . This value indicates that 73 percent of the information contained in the observed variable can be represented by the latent variable of behavior intention.

3.3 Goodness of Fit of the Overall Model

Goodness of fit of the overall test is an overall evaluation of the degree of suitability or Goodness of Fit (GoF) between the data and the model. Structural Equation Modeling (SEM) does not have GoF measures that can be used as a basis for evaluating the suitability of an entire model exclusively, but rather considering several existing GoF measures (Wijanto, 2008).

The GoF test results attached to Appendix VII present that the SEM model obtained meets 9 good of fit criteria, 2 marginal fit criteria, and 4 unfavorable criteria. Therefore, it can be considered that the resulting model is a good model. Furthermore, interpretation of the resulting structural model is carried out. Structural model analysis is related to the evaluation of parameters that show causal relationships between latent variables. This analysis can answer the research hypotheses including:

3.3.1 Perceived Usefulness (PU)

Figure 13 illustrates the path diagram and the structural model equation for the perceived usefulness produced based on the results of processing using Lisrel 8.7. 


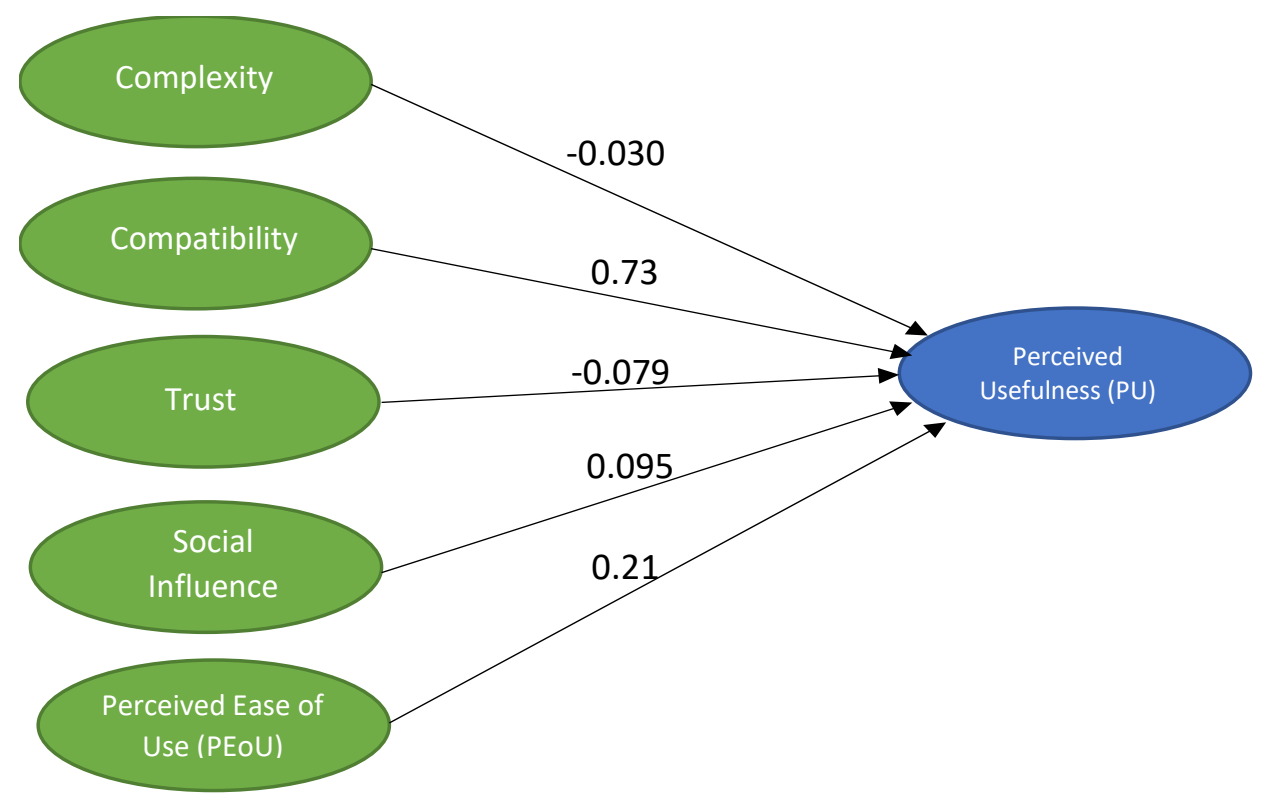

Fig. 13. Path Diagrams of the Latent Variables of Complexity, Compatibility, Trust, Social Influence, and Perceived Ease of Use on Perceived Usefulness

Source: Processed from Lisrel 8.7

$$
\begin{aligned}
& \mathrm{PU}=-0.030 * \text { Complexity }+0.73 * \text { Compatibility }-0.079 * \text { Trust }+0.095 * \text { Social Influence } \\
& +0.21 * \text { PEoU se (o.033) (o.17) (o.069) (o.13) (o.053) t-value }-0.904 .24-1.130 .723 .96 \\
& \text { The above equation shows the correlation between the variables of complexity, compatibility, }
\end{aligned}
$$
trust, social influence, and perceived ease of use toward perceived usefulness. Path parameter coefficient obtained from the correlation between compatibility and perceived usefulness variables is 0.73 with a t-statistic value of 4.24 . This value is more than 1.645 at the significance level $\alpha=$ 0.05. Therefore, with a confidence level of 95 percent, it can be concluded that there is a significant effect between taxpayers' perceptions regarding the compatibility variable to the taxpayer's perceived usefulness. These findings are consistent with the findings of $\mathrm{Fu}$ et al. (2006) which concluded that compatibility affects PU. The positive value of the parameter coefficient means that better taxpayers' perception of the compatibility variable which includes the results that are not contradictory and the same as the manual method and to meet the taxpayers' expectation; thus, taxpayers' perceived usefulness in the use of e-filing is better.

Meanwhile, path parameter coefficients obtained from the correlation between the variables of perceived ease of use and perceived usefulness is 0.21 with a statistic value of 3.96. This value is more than 1.645 at the significance level $\alpha=0.05$. Therefore, that with a confidence level of 95 percent, it can be considered that there is a significant effect between the taxpayers' perception regarding the variable of perceived ease of use toward the taxpayers' perceived usefulness. These findings are in accordance with the findings of Chang et al. (2005) and Davis et al. (1989). The positive value of the parameter coefficient means that better taxpayers' perception regarding the variable of perceived ease of use includes the ease of learning and operating the e-filing in which it will get better perceived usefulness experienced by the taxpayers in the use of e-filing.

Meanwhile, the path parameter coefficient obtained from the correlation between the variables of complexity, trust, and social influence with perceived usefulness has a t-statistic value of less than 1.645 at a significance level of $\alpha=0.05$. Therefore, with a confidence level of 95 percent it can be concluded that there is no significant effect between taxpayers' perception of complexity, trust, and social influence and the taxpayers' perceived usefulness.

3.3.2 Perceived Ease of Use (PEoU)

Figure 14 illustrates the path diagram and structural model equation for perceived ease of use produced based on the results of processing using Lisrel 8.7. 


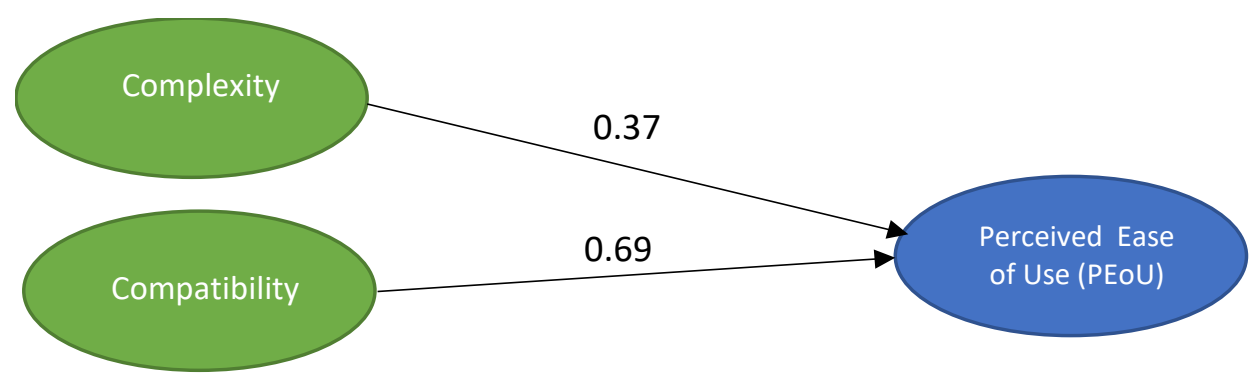

Fig. 14. Path Diagram of Latent Variables of Complexity and Compatibility toward Perceived Ease of Use Source: Processed from Lisrel 8.7

PEOU $=-$

$0.37^{*}$ Complexity $+0.69^{*}$ Compatibility

se (0.039) (0.082) t-value -9.61; 8.36

The above equation shows the correlation of the variables of complexity and compatibility toward perceived ease of use. Path parameter coefficient obtained from the correlation of the variables of complexity toward perceived ease of use is -0.37 with a t-statistic value of -9.61 . This value is bigger than 1.645 at the significance level $\alpha=0.05$. Therefore, with a confidence level of 95 percent, it can be concluded that there is a significant effect between taxpayers' perceptions of the complexity variable on taxpayers' perceived ease of use of. This finding is consistent with the research conducted by Lu et al. (2003) which concluded that complexity has effect toward PEoU. The negative value of the parameter coefficient means that the taxpayers' perception is more complicated which includes difficulties in understanding and operating the e-filing in which the perceived of ease of use or convenience values will get worse.

Meanwhile, the path parameter coefficient obtained from the correlation between the variables of compatibility and perceived ease of use is 0.69 with a t-statistic value of 8.36. This value is bigger than 1.645 at a significance level of $\alpha=0.05$. Therefore, with a confidence level of 95 percent, it can be concluded that there is a significant effect between taxpayers' perceptions of the compatibility variable on taxpayers' perceived ease of use. This finding is consistent with the finding of $\mathrm{Fu}$ et al. (2006) which concluded that compatibility affects PEoU. The positive value of the parameter coefficient means that the better the taxpayer's perception of compatibility or comfort variables (which include results that are not contradictory and the same as the manual method and meet the expectations of taxpayers in using e-filing applications), the better the taxpayers' perceived ease of use or perceived convenience in terms of using the e-filing.

\subsubsection{Attitude Toward Using}

Figure 15 illustrates the path diagram and the structural model equation for 'attitude towards using' based on the results of processing using Lisrel 8.7.

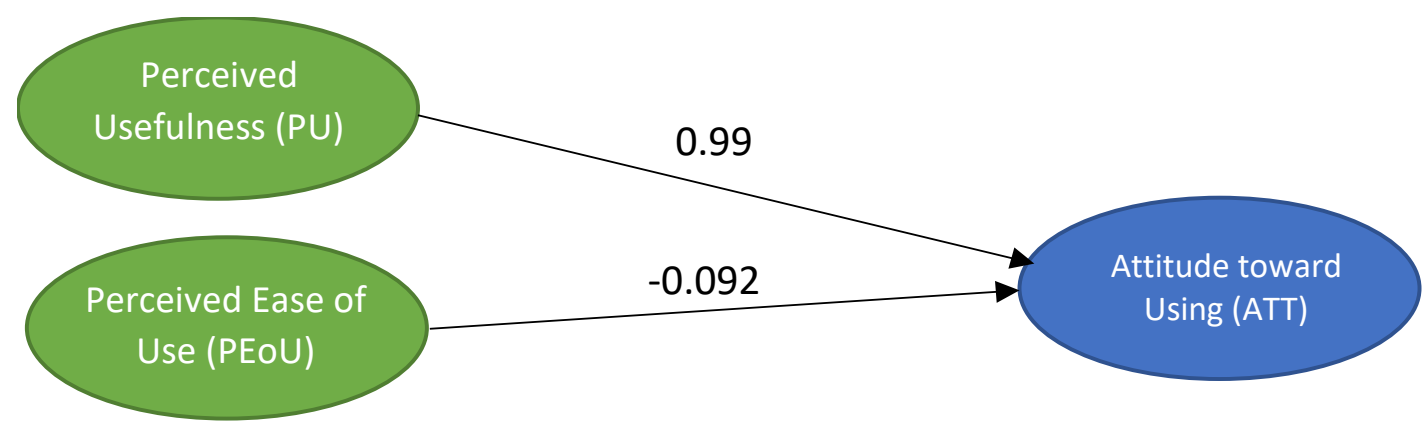

Fig. 15. Path Diagram of Latent Variables of Perceived Usefulness and Perceived Ease of Use on Attitude Towards Using Source: Processed from Lisrel 8.7 


$$
\begin{array}{lcc}
\text { ATT } & =0.99^{*} \mathrm{PU}-0.092^{*} \mathrm{PEoU} \\
\mathrm{se} & (0.10) & (0.060)
\end{array}
$$

$\mathrm{t}$-value $9.83 \quad-1.54$

The above equation shows the correlation between perceived usefulness variables and perceived ease of use on attitude toward using. Path parameter coefficient obtained from the correlation between perceived usefulness variables and attitude toward using is 0.99 with a t-statistic value of 9.83. This value is bigger than 1.645 at the significance level $\alpha=0.05$. Therefore, with a confidence level of 95 percent it can be concluded that there is a significant effect between taxpayers' perception regarding the variable of perceived usefulness on taxpayers' attitude toward using. This finding is consistent with the findings of Hung et al. (2006) which found that PU has effect on attitude. The positive value of the parameter coefficient means that the better the taxpayers' perception regarding the variable of perceived usefulness (which includes faster, cheaper costs, and reduced errors), the better the taxpayers' attitude towards using in terms of using the e-filing.

Meanwhile, path parameter coefficients obtained from the correlation between the variables of perceived ease of use and attitude towards using have a t-statistic value of less than 1.645 at a significance level of $\alpha=0.05$. Thus, with a confidence level of 95 percent it can be concluded that there is no significant effect between taxpayers' perception of the variable of perceived ease of use and taxpayers' attitude towards using.

\subsubsection{Attitude Toward Using}

Figure 16 illustrates the path diagram and the structural model equation for the behavior intention based on the results of processing using Lisrel 8.7.

The equation below presents the correlation between the variables of attitude towards using, social influence, trust, facilitating condition, and perceived risk toward behavior intention. Path parameter coefficient obtained from the correlation between the variables of attitude toward using and behavior intention is 0.40 with a statistic value of 6.15 . This value is bigger than 1.645 at the significance level $\alpha=0.05$. Therefore, with a confidence level of 95 percent, it can be concluded that there is a significant effect between the taxpayers' perception regarding the variables of attitude towards using on taxpayer's behavior intention. This finding is in line with the theory proposed by Ajzen, Fishbein (1980) and the research findings from Hung et al. (2006). The positive value of the parameter coefficient means the better the taxpayers' perception regarding the variable of attitude toward using (which includes 'love the idea' and 'pleasant experience' of e-filing in using it, the better the taxpayers' behavior intention.

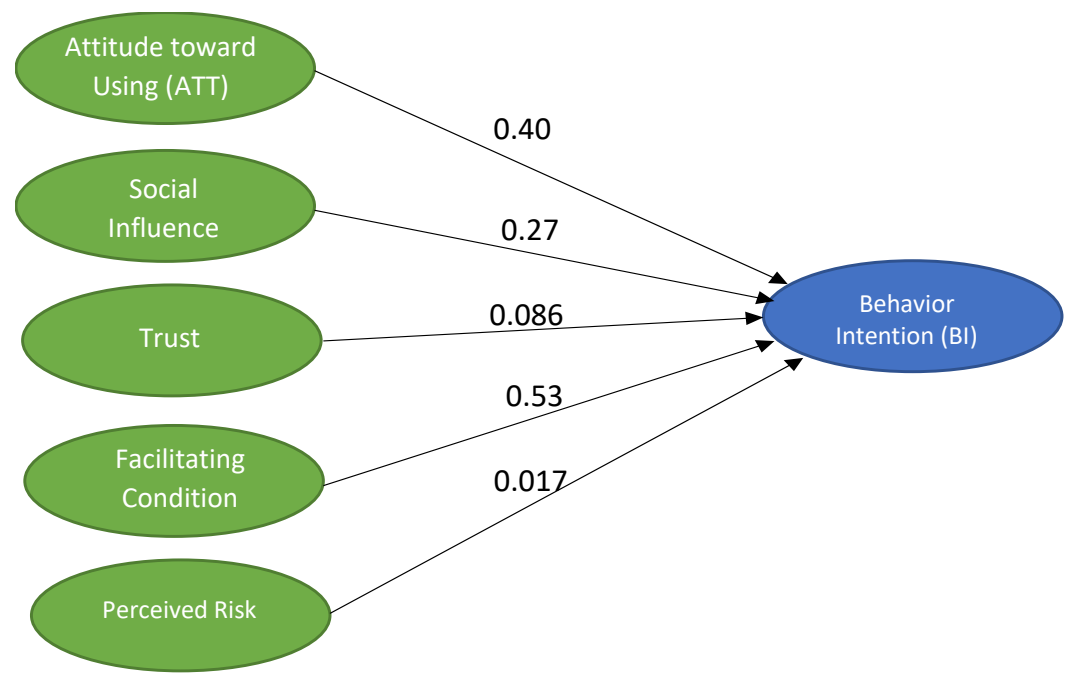

Fig. 16. Path Diagram of Latent Variables of Attitude toward Using, Social Influence, Trust, Facilitating Condition, and Perceived Risk on Behavior Intention

Source: Processed from Lisrel 8.7

$\mathrm{BI}=0.40^{*} \mathrm{ATT}+0.27^{*}$ Social Influence+0.086*Trust $+0.53^{*}$ Facilitating Cond $+0.017^{*}$ Risk se (0.065) (0.12) (0.054) (0.099) (0.038) t-value 6.15; 2.30; 1.58; 5.33; 0.45 
Furthermore, the path parameter coefficient obtained from the correlation between the variables of social influence and behavior intention is 0.27 with a t-statistic value of 2.30. This value is bigger than 1.645 at the significance level $\alpha=0.05$. Therefore, with a 95 percent confidence level, it can be concluded that there is a significant effect between taxpayers' perception regarding the variable of social effect on taxpayers' behavior intention. This finding is in accordance with the TAM theory proposed by Davis et al (1989). The positive value of the parameter coefficient means that the better the taxpayers' perception of social influence variable (which includes the role of the media, the role of the government, and the role of the tax officer in advising the use of e-filing), the better the taxpayers' behavior intention.

Path parameter coefficient obtained from the correlation between the variables of facilitating condition and behavior intention is 0.53 with a t-statistic value of 5.33 .

This value is bigger than 1.645 at the significance level $\alpha=0.05$. Therefore, with a confidence level of 95 percent, it can be concluded that there is a significant effect between taxpayers' perception regarding the variable of facilitating condition on the taxpayers' behavior intention. This is consistent with research conducted by Triandis (1977) who mentioned that the absence of facilities resources could inhibit the use. Thus, a taxpayer does not want to receive e-filing when there is a little or no computer equipment is available and when the technical support is low. The positive value of the parameter coefficient means that the better the taxpayers' perception of the variable of social influence (including the availability of hardware and software, the ease of access to e-filing sites, and the help of tax officers), the better the taxpayers' behavior intention.

Meanwhile, the path parameter coefficient obtained from the correlation between the variables of trust and perceived risk toward behavior intention has a t-statistic value of less than 1.645 at the significance level $\alpha=0.05$. Thus, with a 95 percent confidence level, it can be concluded that there is no significant effect between taxpayers' perception on the variables of trust and perceived risk toward behavior intention.

3.5 Implications of the Research Findings

The above research findings conclude that the complexity variable does not affect taxpayers' perceived usefulness. It means that the taxpayers consider that the difficulty in operating the efiling has no effect or does not become a significant problem. Currently, it is due to high taxpayers' dependence level on tax officers. Based on the observations, there are still many taxpayers who choose to fill out e-filing reports manually by coming to the tax office so that they can be assisted by the tax officers. This fact is also supported by the research findings that the observed variable of 'tax officer assistance' has the greatest contribution to the formation of the latent variable of facilitating condition.

This is different from the findings of $\mathrm{Lu}$ et al. (2003) in their journal entitled Technology Acceptance Model for Wireless Internet which concluded that complexity has effect on PU. Complexity can also affect the satisfaction of a technology that can later encourage users to use it in the future. This encouragement does not appear in using the e-filing due to the element of taxpayers' compulsion and behavior who prefer to come to the tax office in filling out the e-filing step by step with the assistance of tax officer.

In addition, it is also found that social influence does not affect taxpayers' perceived usefulness. It means that the role of government, media and tax officers in persuading taxpayers to use e-filing does not necessarily make taxpayers believe that e-filing is useful for them. It is basically due to the compulsion like what happened to the civil servants who are required to use efiling. Moreover, the tax office seems to force the taxpayers to use e-filing to achieve the required target. It also explains why the observed variable of the role of tax officer has the highest effect in the latent variable of social influences.

In contrast to what Davis et al (1989) mentioned in their TAM model which mentioned that environmental influences have effect on with perceived usefulness. Social influence can have a significant effect on perceived usefulness if the use of the system can give them status and influence in the work group and thus improve their job performance which they do not get in the use of e-filing.

Regarding the variable of 'perceived ease of use' having no effect on attitude towards using, it can be interpreted that taxpayers do not consider that the ease of operating the e-filing can encourage them to use it. It can be caused by the high dependence level of taxpayers to the tax officers. 
Although this finding is not in accordance with the TAM model of Davis (1989) who mentioned that perceived ease of use has a significant effect on attitude toward using, in his own journal, Davis stated that perceived ease of use has a very small effect compared to perceived usefulness on attitude toward using, i.e. 0.02:0.36. This small finding then becomes insignificant because taxpayers are still very dependent on tax officers in filling the e-filing.

Other research findings conclude that trust variable has no effect on taxpayers' perceived usefulness and behavior intention. It means that the trust in the system and the trust that the system has carried out its job properly does not become taxpayers' concern in the use of e-filing or which is a consideration that e-filing is useful. This could be due to the high level of trust in the government in 2016. The latest report of the Organization for Economic Cooperation and Development, OECD, noted that the level of public trust in the Indonesian government in 2016 was 80 percent; an increase of 28 percent compared to 2007 which was only 52 percent. The level of taxpayer's formal compliance based on DGT's performance report data was $62.96 \%$ in 2017.

Gefen (2003) in his journal entitled 'Trust and TAM in Online Shopping: An Integrated Model' found that trust has a positive effect on BI and PU. Trust is needed in order to build trustbuilding mechanisms between users and application owners; in this case, between taxpayers and the government. Trust will only have effect if there is no coercion element in the use of the application in which it does not apply to e-filing. Even though the taxpayers are not sure whether the system has carried out its duties correctly or not, taxpayers inevitably have to report their taxes through e-filing.

Last, the variable of perceived risk does not have effect on taxpayers' behavior intention, which means that the security of personal data, convenience, and privacy and data security do not become their concerns in the use of e-filing. It can be due to the existence of Article 34 of Law number 6 of 1983 as lastly amended by Law Number 28 of 2007 concerning General Provisions and Tax Procedures which regulates the confidentiality of taxpayers' data. It reassures the taxpayers that their data stored in the e-filing application are safe.

Different findings are found by Gefen (2003) who stated that perceived risk has effect on behavior intention. Gefen mentioned that risk is one of the mediators in trust in using the application, or it means that the lower the risk, the higher the level of user confidence. However, in this study, the risk has no significant effect on BI with the reasons mentioned above which is in line with the insignificant effect of trust on BI.

\section{Conclusion}

Based on the research findings and discussion described in the previous chapter, the following conclusions can be drawn:

The variable of compatibility and perceived ease of use have significant effect on perceived usefulness. The taxpayers find that if the application provides results that are not contradictory and the same as the manual method and meet expectations, the e-filing application is considered to be useful. In addition, the ease of learning and operating the e-filing is also a consideration of the usefulness of the application.

Meanwhile, the variables of complexity, trust, and social influence do not have significant effect on taxpayers' perceived usefulness. Complexity variable does not have effect on taxpayers' perceived usefulness, which means that taxpayers do not consider that the difficulty in operating e-filing has no effect or is not a significant problem.

On the other hand, social influence variable does not have effect on taxpayers' perceived usefulness which indicates that the role of the government, the role of the media and the role of tax officers in persuading taxpayers to use e-filing does not necessarily make taxpayers consider that e-filing is useful for them.

The variables of complexity and compatibility have significant effect on perceived ease of use. It means that the level of difficulty in understanding and operating the e-filing and convenience includes results that are not contradictory and the same as the manual method and fulfill the expectations of taxpayers in using e-filing applications to consider whether or not the application is easy to operate.

The variable of perceived usefulness has significant effect on attitude toward using. Taxpayers consider that if the e-filing application can make the reporting faster, lower costs, and reduced errors, it will increase the desire of taxpayers to use e-filing. 
However, it turns out the variable of perceived ease of use does not have effect on attitude toward using. Taxpayers do not consider that the ease of operating e-filing can encourage them to use it. It is due to the high level of taxpayers' dependence on tax officers in terms of helping to direct the filling of ATRs using e-filing. Although the research findings found that the convenience variable is still a significant factor to consider the usefulness of e-filing for the taxpayers, it turns out that these factors are still not significant to encourage taxpayers to use it.

The variables of attitude toward using, social influence, and facilitating condition have significant effect on behavior intention. Variable of attitude towards using, which includes love the idea' and 'pleasant experience' of e-filing, is the consideration of taxpayers in using e-filing in the following years even though in this case the taxpayer cannot stop using once they decided to use it. In this case, it would be more appropriate if the measure of attitude towards using has effect on the satisfaction level of the taxpayers in using e-filing in following years.

In addition, social influence variable, which include the role of the media, the role of the government, and the role of tax officers in providing recommendations for the use of e-filing, in fact has effect on taxpayers' intention behavior; although it has no effect in determining whether the application is useful or not.

The facilitating condition variable, which includes hardware and software availability, ease of access to e-filing sites, and assistance from tax officers, also has significant effect on taxpayers' behavior intention.

Trust variable does not have effect on taxpayers' perceived usefulness and behavior intention. It means that the trust in the system and the trust that the system has carried out its job properly does not become taxpayers' concerns in the use of e-filing or does not become a consideration that the e-filing application is useful.

Lastly, perceived risk variable does not have effect on taxpayers' intention behavior. It means that the security of personal data, convenience, and privacy and data security are not taxpayers' concerns in using the e-filing.

\section{References}

Ajzen, Fishbein, 1980 - Ajzen, I., Fishbein M. (1980). Understanding attitudes and predicting social behaviour, Englewood, Cliff, NJ.

Armstrong et al., 2014 - Armstrong, G., Adam, S., Denize, S., Kotler, P. (2014). Principles of marketing. Pearson Australia.

Chang et al., 2005 - Chang, I-Chiu et al. (2005). An empirical study on the impact of quality antecedents on tax payers' acceptance of Internet tax-filing systems. Government Information Quarterly, (22), 389-410.

Davis et al., 1989 - Davis, F.D., Bagozzi, R.P., Warshaw, P.R. (1989). User acceptance of computer technology: A comparison of two theoretical models. Management Science, 35, 9821003.

Fornell, Larcker, 1981 - Fornell, C., Larcker, D.F. (1981). Structural equation models with unobservable variables and measurement error: Algebra and statistics. Journal of marketing research, 382-388.

Fu et al., 2006 - Fu, Jen-Ruei, Cheng-Kiang Farn, Wen-Pin Chao (2006). Acceptance of electronic tax filing: A study of taxpayer intentions. MIS Quarterly, 43(4), 389-400.

Gefen et al., 2003 - Gefen, D., Karahanna, E., Straub, D. (2003). Trust and TAM in online shopping: an integrated model. MIS Quarterly, 27, 51-90.

Hair et al., 2012 - Hair, J.F., Sarstedt, M., Ringle, C.M., Mena, J.A. (2012). An assessment of the use of partial least squares structural equation modeling in marketing research. Journal of the academy of marketing science, 40(3), 414-433.

Hung et al., 2006 - Hung, S., Chang, C., Yu. (2006). Determinants of user acceptance of the eGovernment services: The case of online tax filing and payment system. Government Information Quarterly, 23, 97-122.

Krejcie, Morgan, 1970 - Krejcie, R.V., Morgan, D.W. (1970). Determining sample size for research activities. Educational and psychological measurement, 30(3), 607-610.

Leisink, Steijn, 2009 - Leisink, P., Steijn, B. (2009). Public service motivation and job performance of public sector employees in the Netherlands. International Review of Administrative Sciences, 75(1), 35-52. 
Lu et al., 2003 - Lu, June et al. (2003). Technology acceptance model for wireless Internet. Emerald, 13(3), 206-222.

Perry, Hondeghem, 2008 - Perry, J.L., Hondeghem, A. (2008). Motivation in public management: The call of public service. Oxford University Press on Demand.

Sekaran, 1992 - Sekaran, U. (1992). Middle-class dual-earner families and their support systems in urban India.

Triandis, 1977 - Triandis, H.C. (1977). Interpersonal Behavior, Brooks/Cole, Monterey, CA. Wijayanto, 2008 - Wijanto, S.H. (2008). Structural equation modelling dengan LISREL 8.8. Yogyakarta: Graha Ilmu. 